\title{
Pendidikan karakter dalam film animasi Riko The Series produksi garis sepuluh
}

\author{
Rizqy Dwi Rahmayanti ${ }^{*}$, Yarno 2 , R. Panji Hermoyo ${ }^{3}$ \\ Pendidikan Bahasa dan Sastra Indonesia, Fakultas Keguruan dan Ilmu Pendidikan, Universitas Muhammadiyah Surabaya, Jalan \\ Sutorejo No.59 Surabaya, Indonesia \\ rrizqydrahmayanti@gmail.com, yarnopbsi@fkip.um-surabaya.ac.id²,panji.pbsi@fkip.um-surabaya.ac.id³ \\ *Corresponding author: rizqydrahmayanti@gmail.com
}

\begin{abstract}
Sejarah Artikel Diterima: IO Februari 202I Direvisi: 23 April 202I Tersedia Daring: 30 April 202I
ABSTRAK

Penguatan karakter sangat penting bagi anak-anak karena ini merupakan peletakan pondasi karakter yang mampu membawa anak tumbuh dengan baik di masa depan. Penelitian ini bertujuan menganalisis, dan mendeskripsikan nilai-nilai pendidikan karakter dalam film animasi Riko The Series produksi Garis Sepuluh. Penelitian deskriptif kualitatif ini menggunakan teknik analisis konten atau isi (content analysis). Sumber data dalam penelitian ini berupa film animasi Riko The Series Produksi Garis Sepuluh yang ditayangkan di platform Youtube. Data dalam penelitian ini berupa kata, frasa, kalimat, dan adegan tokoh. Data dikumpulkan dengan teknik simak catat. Analisis data menggunakan konsep Miles dan Huberman dengan tiga tahap. Pertama, reduksi data yang meliputi langkah menyeleksi, meringkas, dan mengklasifikasi data. Kedua, penyajian data sesuai dengan klasifikasi fokus penelitian. Ketiga, pembuatan simpulan berdasarkan data yang telah dikumpulkan sesuai dengan fokus penelitian. Hasil analisis menunjukkan bahwa Riko memiliki karakter unggul atau baik (good character). Karakter tersebut meliputi (I) religius, (2) rasa ingin tahu tinggi, (3) kerja keras, (4) kreatif, (5) mandiri, (6) menghargai prestasi, dan (7) tanggung jawab. Dari penelitian ini dapat disimpulkan bahwa karakter-karakter unggul tersebut bisa digunakan untuk penguatan pendidikan karakter bagi anak di masa pandemi Covid-19. Diperlukan proses panjang, pengetahuan, contoh, praktik, dan pembiasaan dalam proses penguatan karakter.
\end{abstract}

\section{Kata Kunci Covid-19, Film Animasi, Pendidikan karakter, Riko The Series}

ABSTRACT

Character reinforcement is very important to children. A strong foundation is essential for their upbringing. This study aimed to analyze and describe the values of character education in the animated film, Riko The Series, produced by Garis Sepuluh. This descriptive qualitative research used content analysis technique. The data were taken from the animated film, Riko The Series broadcasted on the Youtube platform included word, phrase, sentences, and scene. The data were collected using the note-taking technique. Data analysis used was the Huberman concept with three stages. First, data reduction including steps to select, to summarize, and to classify data. Second, the presentation of the data that was in accordance with the classification of the research focus. Third, conclusion drawing. This film shows the life of a child who has a smart and sophisticated robot friend and a religious family. Riko also has good environmental support. The results of the analysis showed that Riko has a superior or good character. These characters consist of (I) religious, (2) curios, (3) hard work, (4) creative, (5) independent, (6) respect for achievement, and (7) responsible. In conclusion, these superior characters can be used to strengthen character education for children during the Covid-I9 pandemic. It takes a long process, knowledge, examples, practice, and habituation in the process of strengthening children's character.

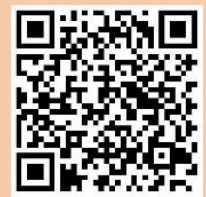

Copyright@202I, Rizqy D Rahmayanti, Yarno, R. Panji H This is an open access article under the CC-BY-3.0 license

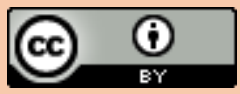

Keywords Covid-I9, Animated film, Character education, Riko The Series

How to Cite Rahmayanti, R. D., Yarno., \& Hermoyo, R. P. (202I). Pendidikan karakter dalam film animasi Riko The Series produksi garis sepuluh. KEMBARA: Jurnal Keilmuan, Bahasa, Sastra dan Pengajarannya (eJournal), 7(I), I57-I72. doi: https://doi.org/10.22219/kembara.v7iI.15139

\section{PENDAHULUAN}

Penguatan karakter sangat penting bagi anak-anak. Peletakan pondasi yang kuat tentu mampu menjadikan seorang anak tumbuh dengan baik di masa depan. Karakter inilah yang membuat perbedaan khusus antara manusia satu dengan lainnya. Sebuah proses yang dijalani untuk membuat manusia mampu memperlakukan manusia lainnya dengan layak disebut pendidikan. Pusat Bahasa Depdiknas (Saraswati, 2016) menyatakan bahwa karakter adalah bawaan hati, jiwa, kepribadian, budi pekerti, perilaku, 
personalitas, sifat, tabiat, temperamen, dan watak. Karakter adalah kualitas atau kekuatan mental, dan moral akhlak atau budi pekerti individu yang merupakan kepribadian khusus yang menjadi pendorong, dan penggerak, serta membedakan antara individu satu dengan individu lain (Kusmanto et al., 2020). Pendidikan karakter dilakukan untuk memperkokoh serta melipatgandakan nilai-nilai kehidupan yang penting untuk seorang individu dalam kehidupan bermasayarakat, dan bernegara (Sulastri et al., 2020). Anak yang tumbuh dengan karakter positif yang kuat, mampu tumbuh, dan berkembang di tengah masyarakat dengan baik, sehingga mempermudah interaksi sosialnya saat berada dalam masyarakat luas (Mustadi, 2018).

Penguatan karakter dilakukan dalam proses fundamental anak, yakni saat anak berada pada masa usia dini. Fondasi pengetahuan, keterampilan, dan sikap, mampu dibentuk, dan dikembangkan pada masa fundamental anak, yakni saat anak berada pada usia dini (Ihsani et al., 2018). Karakter positif yang diaplikasikan dalam kehidupan anak sejak dini bertujuan untuk membentuk kebiasaan tersebut terbawa hingga dewasa (Cahyaningrum et al., 2017). Karakter tidak hanya disampaikan secara lisan, melatih atau menerapkannya pada aktivitas keseharian anak adalah hal penting, agar menciptakan habbit atau kebiasaan yang baik di masa depan. Otak anak akan merespon segala sesuatu yang dia peroleh pada usia fundamental. Segala sesuatu yang dialami oleh anak pada usia 0-3 tahun berpengaruh terhadap kehidupan dewasa anak (Ambarwati, 2016).

Pengembangan platform pendidikan nasional, yang memprioritaskan pendidikan sebagai jiwa utama dalam penyelenggaraan pendidikan bagi peserta didik, diiringi dengan dukungan keterlibatan publik melalui jalur formal, non-formal, dan informal dengan memperhatikan keanekaragaman budaya bangsa Indonesia. Dalam menerapkan Penguatan Pendidikan Karakter (Shidiq \& Raharjo, 2018), revitalisasi, penguatan potensi serta kompetensi pendidik, dari tenaga kependidikan, peserta didik, masyarakat serta lingkungan keluarga perlu dilakukan. Membangun generasi yang memiliki karakter unggul memerlukan sebuah proses pendidikan (Kusmanto et al., 2020).

Penguatan pendidikan karakter perlu difasilitasi oleh guru atau pengajar sebagai pendidik di sekolah. Di sekolah, karakter bisa dipraktikkan sehari-hari dirangkai dengan kegiatan belajar yang lain. Nilai-nilai moral yang ditanamkan kepada anak di sekolah bertujuan untuk memberikan dasar dalam diri mereka, agar mampu berinteraksi dengan baik di tengah masyarakat (Sulistiyo et al., 2020). Namun, kondisi saat ini yang sedang pandemi, secara tidak langsung memaksa anak untuk melakukan Pembelajaran Jarak Jauh (PJJ). Pembelajaran harus dilakukan di rumah untuk mencegah rantai penyebaran Covid-I9. Perkembangan teknologi mampu membantu proses pembelajaran melewati jarak (distance learning), sehingga proses belajar dimana saja tidak menjadi sebuah masalah (Sakerebau, 2018).

Dalam proses pembelajaran jarak jauh, berbagai manfaat dapat kita peroleh dari media digital, termasuk dalam meningkatkan keterlibatan peserta didik dalam konteks pendidikan. Media digital mampu menjadi inovasi yang menarik dalam proses pembelajaran di era pandemi, selain itu media digital dalam proses pendidikan mampu menarik peserta didik untuk lebih berperan aktif (Damayanti et al., 2018).

Secara teoretis, karya sastra mampu memberikan kontribusi dalam proses pembentukan, dan pengembangan karakter seseorang (Anggraini, 20I7; Setiawan \& Qur'ani, 20I7). Karya sastra memiliki khas atau keunikan tersendiri, tidak hanya sebatas tulisan, namun karya sastra dalam bentuk drama juga memiliki kemungkinan untuk dipentaskan (Zaeni, 2015). Film merupakan karya sastra dalam bentuk drama yang berhasil dipentaskan menggunakan perkembangan teknologi dengan adanya media digital. Film animasi bisa menjadi salah satu alternatif yang cocok untuk disajikan kepada anak. Film animasi merupakan salah satu media yang sesuai untuk menanamkan nilai karakter (Sayekti, 2019). Orang dewasa maupun anak-anak, dapat memperoleh banyak manfaat dari sastra (Purbarani, 2010).

Kriteria film animasi yang mampu dijadikan media pembelajaran, yakni mudah dipahami dan simpel. Selain itu, ceritanya efektif, bahasanya santun, dan berisi permainan yang menghibur. Juga nilai yang terkandung di dalamnya dapat ditangkap siswa dengan mudah (Fathurohman et al., 2015). Film animasi Riko The Series memenuhi kriteria film animasi yang mampu dijadikan media pembelajaran. 
Kebiasaan anak dalam meniru karakter tokoh film animasi yang ditontonnya perlu mendapat perhatian khusus, agar anak mendapatkan tontonan yang layak. Media yang tepat mampu menstimulus serta memotivasi siswa dalam proses belajarnya (Melasarianti \& Andini, 2016). Film sebagai media pengajaran mampu membantu proses pendidikan untuk menyampaikan pesan yang terkandung di dalamnya dengan mudah (Nugrahani, 2017).

Film Riko The Series ditayangkan di platform Youtube. Film animasi Riko The Series mengusung konsep edutaintment. Artinya, film ini mengusung dua konsep sekaligus, yakni konsep edukasi dan entertainment. Hal ini menjadi kesempatan yang baik untuk pendidik dalam menanamkan pendidikan karakter dengan cara yang asyik pada masa belajar dari rumah akibat wabah Covid-I9 ini. Di berbagai kisah dalam setiap episode yang disajikan, Riko mampu menguras perhatian penonton untuk mengikuti kisahnya. Ceritanya yang asyik, seru, dan menarik mampu membuat penonton mengikuti keseharian Riko. Inilah pentingnya penerapan dalam aplikasi teori pendidikan karakter melalui film Riko.

Film ini menceritakan keseharian Riko bersama robot kuning kesayangannya, QI IO (Qio). Riko mempunyai keluarga yang lengkap; bunda, ayah, dan Kak Wulan. Dalam film ini Riko merupakan sosok yang bersemangat, selalu tertarik akan hal baru, dan mandiri. Tumbuh dalam keluarga yang religius, dan berpendidikan membuat Riko tumbuh menjadi anak yang religius pula. Ia pun selalu penasaran dengan hal-hal baru yang ditemui.

QIIO merupakan robot hasil kecerdasan buatan (artificial intelligence) yang berperan penting dalam film ini. Setiap hal yang ingin diketahui Riko dapat dijelaskan oleh QIIO menggunakan kecanggihannya. Dengan demikian, pengetahuan baru yang didapatkan oleh Riko melalui proses imajinasi yang menarik dan scientist. Semua yang dijelaskan oleh QIIO berdasarkan ilmu pengetahuan. Penjelasannya dibuat sangat asyik dan menarik, disertai dengan bahasa yang mudah dimengerti oleh anakanak.

Penelitian (Sayekti, 2019), yang menganalisis Film Animasi Nussa dan Rara Episode Baik Itu Mudah serta hubungannya dengan pembelajaran di sekolah dasar. Hasil penelitian ini meliputi (I) film animasi Nussa dan Rara episode baik itu mudah memuat 6 nilai karakter. Hasil penelitian tersebut membuktikan bahwa film animasi mengandung nilai pendidikan karakter yang baik, untuk ditanamkan kepada anak sejak usia dini. Dalam tulisan ini, penulis fokus kepada identifikasi karakter dalam episode tersebut. Artikel berjudul Film Animasi sebagai Media Pembelajaran Terpadu untuk Keaksaraan Multibahasa pada Siswa di Sekolah Dasar yang ditulis (Fathurohman et al., 2015), berisi bahwa film animasi multibahasa mampu menjadi media dalam pembelajaran pengenalan bahasa bagi siswa di sekolah dasar. Dalam artikel tersebut, peneliti membuktikan bahwa film animasi multibahasa mampu membantu proses pengenalan bahasa dalam pembelajaran siswa sekolah dasar. Analisis Strategi Dakwah dalam Film Riko The Series (Studi pada Youtube Riko The Series) karya Muhammad Izuddin Febrianta (2020) menyebutkan bahwa film animasi Riko The Series berisi konten dakwah yang dapat menjadi pilihan orang tua untuk tontonan anaknya. Penelitian ini mengidentifikasi nilai dakwah yang ada dalam film Riko The Series. Penelitian lain yang mempunyai relevansi dengan penelitian ini ada dalam skripsi berjudul Pendidikan Akhlaq dalam Film Animasi Nussa dan Rara Produksi The Little Giantz (2019), karya (Demillah, 2019). Penelitian ini mengidentifikasi pendidikan akhlak yang ada di dalam film Nussa dan Rara. Peneliti mengambil kesimpulan bahwa film animasi Riko The Series mampu menjadi media penguatan pendidikan karakter dalam diri seorang anak.

Kebaruan dalam penelitian ini dengan penelitian yang telah disebutkan di atas ada tiga faktor. Pertama, dari sisi objek film yang dianalisis yaitu film animasi berjudul Riko The Series, belum ada penelitian mengenai pendidikan karakter dengan menggunakan objek kajian film animasi Riko The Series sebagai media pendidikan karakter, sehingga ini menjadi kebaruan dalam penelitian ini. Kedua, penelitian ini mengidentifikasi karakter tokoh utama Riko yang menyajikan karakter-karakter baik yang layak dijadikan contoh bagi penguatan karakter anak. Ketiga, kajian terhadap film animasi Riko The Series sebagai media penguatan dalam pendidikan karakter anak dirasa sesuai dengan kondisi pembelajaran pada masa pandemi Covid-19 untuk melakukan penguatan karakter melalui edukasi nonformal. Orang tua

Rizqy Dwi Rahmayanti, Yarno, \& R. Panji Hermoyo, Pendidikan karakter dalam film animasi Riko The Series produksi garis sepuluh 
dapat memanfaatkan film animasi tersebut untuk menguatkan karakter anak-anak melalui pendidikan di rumah. Peneliti meyakini bahwa pendidikan nonformal akan memberikan dampak lebih besar bagi anak. Sebab, situasi ini berlangsung sepanjang hayat. Mulai anak usia dini hingga dewasa nanti. Untuk itu, menggunakan film animasi Riko The Series untuk menguatkan karakter bagi anak-anak merupakan suatu alternatif yang sangat baik.

Penelitian ini difokuskan pada analisis pendidikan karakter di dalam film animasi Riko The Series. Karakter-karakter Riko dalam film tersebut dapat dijadikan teladan bagi anak-anak. Melalui pengkajian tersebut, diharapkan penelitian ini mampu memberikan kontribusi di bidang pendidikan, khususnya melalui sastra dengan nilai-nilai karakter sebagai fokus utama. Peneliti lain tentu dapat mengembangkan penelitian yang masih berhubungan dengan nilai pendidikan karakter di dalam film animasi. Semoga masyarakat bisa mengambil intisari akan pentingnya nilai pendidikan karakter, khususnya menguatkan pendidikan karakter yang baik bagi anak-anak sejak dini.

\section{METODE}

Penelitian ini menggunakan metode penelitian deskriptif kualitatif, yang identik dengan deskripsi serta intrepretasi data-data yang ada dalam film animasi Riko The Series. Penelitian kualitatif biasanya digunakan untuk penelitian yang bersifat sosial atau mengenai kehidupan masyarakat, dan lain-lain. Data yang diperoleh bersumber dari youtube channel Riko The Series. Dari film animasi tersebut diambil data berupa kata, frasa, kalimat, dan adegan tiap tokoh yang sesuai dengan fokus penelitian, yang meliputi: karakter religius, rasa ingin tahu, kerja keras, kreatif, mandiri, menghargai prestasi, dan tanggung jawab. Teknik pengumpulan data menggunakan teknik simak dan catat. Oleh sebab itu, penelitian ini menggunakan teknik analisis konten/isi (content analysis) (Sayekti, 2019).

Instrumen penelitian ini adalah film animasi Riko The Series season I. Data yang diperlukan lantas diklasifikasi dengan melihat, mendengar, dan mencatatnya. Berdasarkan fokus penelitian dan tujuan penelitian, analisis data dilakukan dengan cara reduksi data, yaitu menyeleksi data, meringkas, serta membuat klasifikasi. Berikutnya, penyajian data dan penarikan simpulan dilakukan berdasarkan konsep yang dikemukakan oleh Hubberman (I994), dalam (Sujinah, 2020).

\section{HASIL DAN PEMBAHASAN}

Orang tua sebagai fasilitator sekaligus penanggung jawab proses pendidikan yang berlangsung di rumah mampu memberikan bimbingan yang layak bagi anak. Orang tua diharapkan mampu memilih media pendidikan yang menarik bagi anak. Sastra bisa dijadikan alternatif untuk pemberian nilai baik dan buruk (Sayekti, 2019). Usia 0-6 tahun merupakan usia yang ideal untuk menanamkan pendidikan karakter kepada anak (Subadi, 2017). Usia ini merupakan usia esensial dalam memberikan pengalaman serta stimulus dalam proses pemberian karakter positif pada anak (Supeni, 2015). Setelah melewati penanaman karakter pada usia 0-6 tahun, selanjutnya orang tua bisa menguatkan karakter positif pada usia 7-I4 tahun. Pada usia ini anak masih menyukai film animasi sebagai hiburan mereka.

Usia 7-I 4 tahun merupakan tahapan yang sesuai untuk menguatkan karakter anak menggunakan film Riko The Series. Kriteria film Riko The Series memenuhi kriteria film animasi yang mampu dijadikan media pembelajaran sesuai dengan kriteria yang telah disebutkan oleh (Fathurohman et al., 2015). Penelitian terdahulu melakukan penelitian terhadap film animasi Nussa dan Rara, sedangkan dalam penelitian ini peneliti menggunakan film animasi Riko The Series sebagai fokus penelitian. Dalam penelitian terdahulu yang menggunakan film animasi Riko The Series berfokus kepada analisis strategi dakwah, sedangkan dalam penelitian ini yang dianalisis adalah karakter tokoh utama Riko yang mampu dijadikan teladan bagi anak-anak. Dalam penelitian lain yang mengidentifikasi pendidikan akhlak dalam film Nussa dan Rara, sedangkan dalam penelitian ini peneliti berfokus kepada keseluruhan karakter yang dmiliki oleh tokoh utama dalam film Riko The Series.

Di tengah pandemi Covid-I9, orang tua memiliki waktu yang lebih banyak untuk berada di rumah. Kebijakan Pemerintah Republik Indonesia tentang bekerja dari rumah memberikan beberapa 
dampak positif bagi anak. Salah satu dampak positifnya adalah anak memiliki waktu lebih banyak bersama orang tuanya di rumah masing-masing. Kesempatan ini dapat dimaksimalkan oleh orang tua untuk membangun dan memperkuat komunikasi yang baik bersama anak-anaknya. Pendidikan merupakan proses sadar untuk mentransfer segala informasi baik, dari orang dewasa kepada anak-anak. Proses untuk mencapai hasil yang memuaskan perlu dilakukan dengan maksimal dalam pembentukan karakter anak (Subadi, 2017).

Dalam situasi pandemi Covid-19, menjalin komunikasi yang harmonis berfungsi untuk mempererat hubungan mereka. Orang tua dapat memberikan penegasan atas pelajaran yang didapatkan oleh anak melalui tontonan yang dinikmati. Mengenalkan anak dengan nilai baik yang patut ditiru, dan nilai buruk yang harus dihindari dapat menggunakan media film animasi. Film animasi merupakan bentuk modern dari cerita anak yang sudah dikembangkan dengan menggunakan teknologi terbaru. Sifat meniru segala hal yang diperoleh dari lingkungan, dan tontonan merupakan sifat yang biasa dimiliki oleh anak usia dini (Cahyaningrum et al., 2017).

Film Riko The Series produksi Garis Sepuluh merupakan film animasi hasil kolaborasi Arie Untung, Teuku Wisnu, dan Yuda Wirafianto. Mereka berkolaborasi dengan menyatukan Garis Sepuluh, Rounbox Animation, dan rumah cerita. Kolaborasi ini bertujuan untuk menciptakan Riko The Series. Film animasi ini diperuntukkan bagi anak balita hingga I5 tahun. Film animasi ini menceritakan kehidupan seorang anak laki-laki yang memiliki anggota keluarga lengkap. Ayahnya berprofesi sebagai seorang dokter, bunda berprofesi jurnalis, dan seorang kakak perempuan bernama Kak Wulan. Selain itu, Riko memiliki robot canggih berwarna kuning bernama QI IO. Film animasi ini menyajikan cerita tentang keseharian Riko bersama keluarga. Dalam kehidupan sehari-hari itu Riko belajar banyak hal baru.

Riko merupakan sosok anak-anak yang selalu penasaran dengan hal-hal baru yang belum diketahui. Kreator film animasi ini sengaja memperkuat karakter keingintahuan Riko dengan menggambarkannya melalui ikon rambut yang berbentuk tanda tanya. Rambut Riko akan tegak berdiri ketika menanyakan sesuatu yang membuatnya penasaran. Kemudian, QI IO sebagai robot canggih akan memberikan jawaban dengan jelas kepada Riko.

QIIO memberikan penjelasan dengan cara yang unik. Liquid crystal display (LCD) dan proyektor akan muncul dari tubuhnya. Dari layar itu QIIO menyampaikan penjelasan dengan bahasa yang mudah dicerna. Selain itu, animasi yang ditampilkan menarik perhatian anak-anak. Penyajian yang lucu dan unik serta berisi tentang edukasi dan entertainment menjadi daya tarik tersendiri bagi penonton. Hal ini sesuai dengan kriteria film sebagai media pengajaran mampu membantu proses pendidikan untuk menyampaikan pesan yang terkandung di dalamnya dengan mudah (Nugrahani, 2017).

Kehidupan Riko yang penuh dengan imajinasi, semangat, keceriaan, humor, kejahilan seorang anak, dan perjalanan Riko mengeksplor dirinya dengan karakter religius, mandiri, kreatif, tanggung jawab, menghargai prestasi, kerja keras dan rasa ingin tahunya yang tinggi tentang sesuatu yang dia temui. Karakter Riko ini bagus untuk menunjang pertumbuhan dan penguatan karakternya di masa depan. Sebetulnya, karakter Riko sangat nyata karena menunjukkan kebiasaan asli anak-anak seusianya yang masih asyik bermain, jahil, dan sangat tertarik tentang banyak hal yang ditemui.

Banyak hal yang bisa dilakukan oleh orang tua dalam memberikan edukasi dan hiburan yang layak bagi anaknya selama pandemi Covid-I9. Film animasi Riko The Series bisa dijadikan salah satu pilihan untuk menguatkan karakter anak-anak. Berdasarkan film animasi Riko The Series season I yang telah dianalisis, ditemukan banyak nilai karakter. Namun, ada beberapa karakter yang secara dominan dimiliki Riko. Karakter tersebut antara lain: (I) religius, (2) rasa ingin tahu, (3) kreatif, (4) mandiri, (5) menghargai prestasi, (6) kerja keras, dan (7) tanggung jawab.

Hasil analisis dalam penelitian ini menunjukkan bahwa beberapa karakter positif di atas dominan dalam beberapa episode dalam film animasi Riko The Series season I. Adegan ini bisa ditiru oleh anakanak sebagai bentuk contoh atau teladan yang baik dan layak diaplikasikan dalam kehidupan sehari-hari. Hal ini sesuai degan teori bahwa film animasi merupakan salah satu media yang sesuai untuk menanamkan nilai karakter (Sayekti, 2019). 
Orang tua memberikan waktu bagi anak-anak menonton film tersebut. Kemudian mereka diberi ruang untuk menyampaikan dan bercerita tentang apa yang telah ditontonnya. Orang tua sebagai fasilitator bisa memberikan penegasan tentang perilaku yang boleh dicontoh dan yang tidak boleh dicontoh untuk diaplikasikan dalam kehidupan sehari-hari. Orang tua dapat melihat dan memantau anakanak untuk menerapkan karakter tersebut di dalam kesehariannya di lingkungan masyarakat. Evaluasi dalam pendidikan karakter bisa dilakukan dengan observasi langsung (Maunah, 2016).

Jadi, hasil dari penelitian ini menunjukkan bahwa film animasi Riko The Series ini layak digunakan sebagai alternatif media penguatan pendidikan karakter bagi anak pada masa pandemi Covid19. Film animasi ini juga dapat digunakan oleh para pendidik untuk melaksanakan edukasi selama penerapan pembelajaran jarak jauh berlangsung.

\section{Pendidikan Karakter Religius}

Tontonan yang layak serta mendidik harus diberikan kepada anak sesuai dengan perkembangan masanya (Demillah, 2019). Film dengan nuansa religius memiliki kesan menyenangkan serta mengedukasi patut untuk dipilih orang tua dan pendidik sebagai alternatif penguatan karakter anak. Dalam film animasi Riko The Series season I diceritakan bahwa Riko berada dalam keluarga yang mempunyai identitas agama Islam. Hal ini dapat terlihat dalam setiap bagian yang ada di dalam filmnya. Beberapa bukti tersebut adalah sebagai berikut.

Sponsor yang logonya ditayangkan di awal mulainya film adalah Wardah dan BNI Syariah. Diketahui bahwa Wardah merupakan salah satu brand ternama dari produk kosmetik yang dikenal dengan kehalalannya. BNI Syariah merupakan Bank Negara Indonesia yang memiliki sistem syariah dalam pengelolaannya. (Riko: Eps. Berani Sama Besi).

Dialog “Assalamualaikum” yang diucapkan Riko saat membuka pintu, dan masuk ke kamarnya. Ini

2 merupakan salam untuk keselamatan yang biasa digunakan bagi muslim ketika bertemu dengan muslim lain maupun saat memasuki suatu ruangan. (Riko: Eps. Berani Sama Besi).

Dialog "Kalau mau ajak main, bilang assalamualaikum dulu dong. Jangan asal main serang aja," kata

3 Riko kepada QIIO yang tiba-tiba menempel di punggungnya karena Riko membawa magnet. Menyapa dengan ucapan salam yang dianjurkan Riko ke QIIO merupakan salah satu bentuk adab yang baik menurut agama Islam. (Riko: Eps. Berani Sama Besi).

Dialog "Terima kasih ya Allah, sudah menurunkan besi untuk manusia”. Dialog ini merupakan salah

4 satu perilaku religius, yaitu bersyukur kepada Tuhan atas anugerah yang diberikan. (Riko: Eps. Berani Sama Besi).

"Bismillah," ucap Riko sebelum mulai memperbaiki mobil-mobilan miliknya yang rusak. Mengawali

5 semua kegiatan dengan menyebut nama Allah merupakan perilaku religius. (Riko: Eps. Mobilku Melaju Cepat).

"Masyaa Allah, QI I0, keren yah Aljazari,” ucap Riko penuh kagum. Kalimat masyaa Allah digunakan

6 untuk mengucap syukur saat mengetahui atau melihat sesuatu yang dikagumi. Perilaku ini juga bagian dari religiusitas. (Riko: Eps. Mobilku Melaju Cepat).

7 "Masyaa Allah, keren banget QIIO," ucap Riko kagum saat melihat kemampuan QIIO bermain kartu acak. (Riko: Eps. Lawan Virus dengan Madu).

"Alhamdulillah, keren kan," ucap Riko setelah menemukan barang yang dicari dan menunjukkan

8 kepada QIIO. Perilaku ini adalah bagian dari sikap yang diterapkan untuk mensyukuri suatu hal kepada Tuhan. (Riko: Eps. Lebih Baik Memaafkan).

"Masyaa Allah, ternyata matahari besar banget ya QI IO," ucap Riko penuh kagum. Kalimat masyaa

9 Allah digunakan untuk mengucap syukur saat mengetahui atau melihat sesuatu yang dikagumi. Perilaku ini juga bagian dari religiusitas. (Riko: Eps. Jarak Matahari dan Bumi).

I0 "Subhanallah, adan maghribnya masih lama yah." Kalimat subhanallah digunakan ketika terkejut akan suatu hal yang tidak diharapkan. (Riko: Eps. Keutamaan Berpuasa). 
"Astagfirullah, aku kan lagi puasa." Istighfar biasanya diucapkan saat mengingat Allah maupun II menyadari kesalahan yang dilakukan, baik yang disengaja maupun tidak. (Riko: Eps. Keutamaan Berpuasa).

"Aku mau main aja deh, biar lupa sama laparnya, Assalamualaikum." Saat hendak berpamitan tidak

I2 lupa Riko mengucapkan salam. Ini juga bagian dari adab yang baik dalam Islam (Riko: Eps. Keutamaan Berpuasa).

"Masyaa Allah, gitu," ucap Riko kagum. Kalimat masyaa Allah digunakan untuk mengucap syukur

I3 saat mengetahui atau melihat sesuatu yang dikagumi. Perilaku ini juga bagian dari religiusitas. (Riko: Eps. Ayahku Pahlawanku).

"Assalamualaikum," ucap Riko saat memasuki ruang kerja ayah. Ini adalah salam untuk keselamatan

I4 yang biasa digunakan untuk orang muslim ketika bertemu dengan muslim lain maupun saat memasuki suatu ruangan. (Riko: Eps. Ayahku Pahlawanku).

"Masyaa Allah, gitu." Kalimat masyaa Allah digunakan untuk mengucap syukur saat mengetahui atau

I5 melihat sesuatu yang dikagumi. Perilaku ini juga bagian dari religiusitas. (Riko: Eps. Tanaman Bertasbih).

“Astagfirullah, bener juga, Riko ada PR.” Istighfar biasanya diucapkan saat mengingat Allah maupun

I6 menyadari kesalahan yang dilakukan, baik yang disengaja maupun tidak. (Riko: Eps. Yuk Hemat Listrik).

"Astagfirullah Bunda. Bunda usil nih," ucap Riko terkejut atas tindakan ibunya. Istighfar biasanya

I7 diucapkan saat mengingat Allah maupun menyadari kesalahan yang dilakukan, baik yang disengaja maupun tidak. (Riko: Eps. Penemu Angka Nol).

"Masyaa Allah. Oh, gitu," ucap Riko kagum. Kalimat masyaa Allah digunakan untuk mengucap

I8 syukur saat mengetahui atau melihat sesuatu yang dikagumi. Perilaku ini juga bagian dari religiusitas. (Riko: Eps. Penemu Angka NoI).

"Uh, waalaikumsalam QII0," ucap Riko kesal. Ini adalah salam untuk keselamatan yang biasa

I9 digunakan untuk orang muslim ketika bertemu dengan muslim lainnya maupun saat memasuki suatu ruangan. (Riko: Eps. Penemu Angka Nol).

"Aku mau shalat dulu, terus berdoa, biar dijadikan anak yang hebat sama Allah." Perilaku ini

20 menunjukkan bentuk ketakwaan seorang muslim, saat mengharapkan sesuatu hendaknya melibatkan Allah. (Riko: Eps. Penemu Angka NoI).

"Masyaa Allah. Oh gitu," ucap Riko kagum. Kalimat masyaa Allah digunakan untuk mengucap

2I syukur saat mengetahui atau melihat sesuatu yang dikagumi. Perilaku ini juga bagian dari religiusitas. (Riko: Eps. Peringatan Kemerdekaan Indonesia).

Manusia yang tumbuh dengan good character atau karakter unggul alias baik adalah manusia yang senantiasa berusaha semaksimal mungkin untuk menghasilkan sesuatu yang terbaik untuk Tuhan Yang Maha Esa, diri sendiri, sesama manusia, lingkungan masyarakat, serta negaranya, baik di tingkat regional maupun internasional secara sadar, menggunakan ilmu, emosi, dan perasaan yang bergerak untuk memotivasi tujuannya (Saraswati, 2016). Proses aplikasi nilai religius atau ketuhanan bertujuan untuk menjadikan manusia lebih siap dalam menghadapi masalah kehidupan yang nantinya akan dihadapi (Arditiya, 2016).

Dari dialog-dialog beberapa episode film animasi Riko The Series di atas dapat disimpulkan bahwa Riko mempunyai karakter religius. Hal ini dipengaruhi oleh keluarga Riko yang merupakan keluarga muslim yang religius. Situasi kondusif dari lingkungan keluarga, teman, dan sekolah merupakan aspek fundamental yang harus dilibatkan dalam pendidikan karakter (Muhtar \& Dallyono, 2020).

Pendidikan merupakan sebuah proses transfer ilmu atau informasi dari orang dewasa kepada anak secara disengaja. Oleh karena itu, orang tua dan anak-anak dapat menonton film animasi Riko The Series bersama. Orang tua bisa segera mengetahui perilaku Riko yang merupakan karakter religius. Orang tua harus memberikan pengertian kepada anak bahwa kebiasaan tersebut adalah hal baik. Mengucapkan salam, kalimat tayibah seperti alhamdulillah, masyaa Allah, subhanallah, astagfirullah, dan inna lillahi merupakan kalimat yang baik jika diterapkan dalam kehidupan sehari-hari.

Rizqy Dwi Rahmayanti, Yarno, \& R. Panji Hermoyo, Pendidikan karakter dalam film animasi Riko The Series produksi garis sepuluh 
Orang tua bisa mulai mencontohkan dengan hal kecil mengucapkan "alhamdulillah" setelah menonton film animasi Riko The Series. Tindakan ini akan diamati oleh anak karena pendidikan adalah proses dan penguatan karakter adalah pembiasaan. Jika anak-anak mengetahui, melihat perbuatan ini di film, dan diterapkan orang tuanya, ada kemungkinan anak akan menirunya. Cepat atau lambat bukanlah masalah. Yang penting dalam menguatkan karakter adalah konsistensi dan kesabaran antara orang tua sebagai fasilitator, dan controlling, serta anak yang memiliki peran sebagai pembelajar. Pendidikan ialah latihan dan pembiasaan diri untuk memperoleh kebiasaan yang diinginkan (Badruzaman et al., 2018).

Agar tidak bosan, orang tua bisa menempelkan gambar tulisan kalimat tayibah dan salam di dinding rumah. Orang tua juga perlu mengingatkan, sebagai motivasi anak, seperti "Wah, Riko anak yang baik yah. Setiap masuk ke kamar, Riko selalu mengucapkan salam. Ya Allah, semoga Riri juga bisa menjadi anak baik seperti Riko yang selalu mengucapkan salam saat masuk ke dalam kamar, Aamiin.” Saat mengucapkan hal ini harus ada anak, dan waktu yang paling tepat adalah sesaat setelah menonton film Riko.

Semua perbuatan Riko yang berunsur religius dan ingin dikuatkan pada anak, orang tua harus memperjelas bahwa hal tersebut layak ditiru. Orang tua meniru, anak menyaksikan, orang tua mengajak menerapkan dalam kehidupan sehari-hari secara konsisten. Pembiasaan ini akan membuat anak tumbuh dengan baik dengan menerapkan karakter religius yang diharapkan. Usaha secara sadar yang datang dari hati manusia untuk mendalami akidah, akhlak, dan ibadah merupakan karakter religius yang harus dikuatkan sedini mungkin (Azizah \& Setiana, 2017).

\section{Pendidikan karakter rasa ingin tahu}

Pada masa pandemi Covid-19, orang tua merupakan sentral dalam proses pendidikan serta penerapan pembelajaran jarak jauh bagi anak. Orang tua berperan penting dalam membimbing, menjaga, serta memberikan pendidikan bagi anak (Kurniati et al., 2020). Dalam film Riko The Series season I diceritakan melalui dialog dan sikap tokoh Riko. Kreator secara khusus menggambarkan rasa ingin tahu Riko yang tinggi melalui ikon rambutnya yang berbentuk tanda tanya. Beberapa dialog Riko yang menunjukkan karakter ini antara lain sebagai berikut. 


\begin{tabular}{|c|c|}
\hline I & $\begin{array}{l}\text { "Terus kenapa QII0 takut sama magnet?” tanya Riko penasaran melihat reaksi QIIO yang tidak } \\
\text { ingin berdekatan dengan magnet. (Riko: Eps. Takut Sama Besi). }\end{array}$ \\
\hline 2 & $\begin{array}{l}\text { "Memang asal muasal besi dari mana sih QII0?" tanya Riko penasaran disertai dengan perubahan } \\
\text { rambutnya membentuk tanda tanya. (Riko: Eps. Takut Sama Besi). }\end{array}$ \\
\hline 3 & $\begin{array}{l}\text { "Siapa itu?" tanya Riko penasaran dengan tokoh yang disebutkan QI IO. (Riko: Eps. Mobilku Melaju } \\
\text { Cepat). }\end{array}$ \\
\hline 4 & $\begin{array}{l}\text { "Aljazari?” Riko bertanya lagi setelah mendengar nama tokoh yang disebutkan QIIO. (Riko: Eps. } \\
\text { Mobilku Melaju Cepat). }\end{array}$ \\
\hline 5 & $\begin{array}{l}\text { "Gimana sih cara mainnya?" tanya Riko penasaran melihat kemampuan QIIO yang ahli dalam acak } \\
\text { kartu (Riko: Eps. Lawan Virus dengan Madu). }\end{array}$ \\
\hline 6 & $\begin{array}{l}\text { "Hah? Minuman apa QIIO?” ujar Riko mendengar penjelasan QIIO tentang minuman yang bisa } \\
\text { menangkal virus (Riko: Eps. Lawan Virus dengan Madu). }\end{array}$ \\
\hline 7 & $\begin{array}{l}\text { "Emang siapa ih? Orang yang bisa ngitung jarak bumi dan matahari?" tanya Riko penasaran (Riko: } \\
\text { Eps. Jarak Matahari dan Bumi). }\end{array}$ \\
\hline 8 & $\begin{array}{l}\text { "QIIO, kenapa sih, kita disuruh berpuasa?” Riko mulai penasaran dan bertanya kepada QI IO. (Riko: } \\
\text { Eps. Keutamaan Berpuasa). }\end{array}$ \\
\hline 9 & $\begin{array}{l}\text { "Kok bisa?" tanya Riko saat QIIO menjelaskan manfaat puasa bagus untuk kesehatan. Riko tetap } \\
\text { bertanya karena rasa ingin tahunya yang besar (Riko: Eps. Keuatamaan Berpuasa). }\end{array}$ \\
\hline 10 & $\begin{array}{l}\text { "Pandemi itu, apa sih?” tanya Riko saat mendengar kata pandemi yang tidak dimengerti. (Riko: Eps. } \\
\text { Ayahku Pahlawanku). }\end{array}$ \\
\hline II & "Hah? Virus? Kayanya Riko pernah dengar di TV deh.” (Riko: Eps. Ayahku Pahlawanku). \\
\hline 12 & $\begin{array}{l}\text { "Ayah, ayah. Kemarin ayah sibuk ngapain sih? Kok ngga pulang-pulang, Riko nungguin tau?” tanya } \\
\text { Riko kepada ayahnya (Riko: Eps. Ayahku Pahlawanku). }\end{array}$ \\
\hline 13 & $\begin{array}{l}\text { "QIIO, virus itu apa sih?” tanya Riko yang disertai dengan perubahan rambutnya berbentuk tanda } \\
\text { tanya. (Riko: Eps. Ayahku Pahlawanku). }\end{array}$ \\
\hline 14 & $\begin{array}{l}\text { "QIIO, kenapa sih, Kak Wulan sedih banget sama tanaman yang patah, kan gampang tinggal beli } \\
\text { lagi?" tanya Riko pada QIIO saat melihat Kak Wulan bersedih melihat tanamannya tidak sengaja } \\
\text { dipatahkan oleh Riko (Riko: Eps. Tanaman Bertasbih). }\end{array}$ \\
\hline 15 & $\begin{array}{l}\text { "QII0, gimana sih, caranya listrik bisa nyalain lampu, dan alat-alat elektronik lainnya," tanya Riko } \\
\text { penasaran disertai dengan berubahnya rambut Riko berbentuk tanda tanya (Riko: Eps. Yuk Hemat } \\
\text { Listrik). }\end{array}$ \\
\hline 16 & "Kok Bunda tahu kalau Riko mau ngagetin Bunda." (Riko: Eps. Penemu Angka Nol). \\
\hline I7 & $\begin{array}{l}\text { "Lagi nulis apa sih Bunda?" Melihat bunda serius mengetik, Riko penasaran (Riko: Eps. Penemu } \\
\text { Angka Nol). }\end{array}$ \\
\hline 18 & "Media online? Apa itu Bunda?" tanya Riko penasaran(Riko: Eps. Penemu Angka Nol). \\
\hline 19 & $\begin{array}{l}\text { "Kak Wulan lagi ngerjain apa sih?” Riko penasaran melihat Kak Wulan sedang serius melihat HP } \\
\text { (Riko: Eps. Penemu Angka Nol). }\end{array}$ \\
\hline 20 & “Kok pake HP?” Riko terheran dan kembali menginginkan jawaban (Riko: Eps. Penemu Angka Nol). \\
\hline $2 \mathrm{I}$ & "Kok bisa?” Riko masih belum puas dengan jawaban Kak Wulan (Riko: Eps. Penemu Angka NoI). \\
\hline 22 & $\begin{array}{l}\text { "Eh QI I0, Bunda kerjanya pakai laptop, Kak Wulan bikin tugasnya pakai HP. Sebetulnya siapa sih } \\
\text { orang yang berjasa sampai bisa lahir komputer dan internet?" rambut Riko berbentuk tanda tanya } \\
\text { (Riko: Eps. Penemu Angka NoI). }\end{array}$ \\
\hline & $\begin{array}{l}\text { "Ayah, kenapa sih, benda kalau jatuh selalu ke bawah?” tanya Riko penasaran dengan jatuhnya } \\
\text { kelereng game nya (Riko: Eps. Peringatan Kemerdekaan Indonesia). }\end{array}$ \\
\hline
\end{tabular}

Riko selalu penasaran dengan hal-hal yang tidak dia ketahui sebelumnya. Terkadang Riko melayangkan pertanyaan beruntun dan menuntut penjelasan serinci mungkin. Beberapa adegan dalam film, rambut Riko membentuk tanda tanya tegas saat dia menanyakan suatu hal.

Orang tua dapat memberikan stimulus dengan lebih sering melakukan kegiatan bersama, seperti mengenalkan anak lebih dalam dengan lingkungan rumahnya. Mempelajari benda-benda di sekitarnya, dari mana asal muasal mereka. Orang tua juga harus menegaskan bahwa bertanya itu baik, malu bertanya membuat kita tidak mengetahui arah. Tidak mengetahui arah bisa membuat kita tersesat. Mindset anak

Rizqy Dwi Rahmayanti, Yarno, \& R. Panji Hermoyo, Pendidikan karakter dalam film animasi Riko The Series produksi garis sepuluh 
yang takut untuk bertanya, dan menyampaikan rasa ingin tahunya harus dibuka terlebih dahulu. Orang tua bisa memberikan stimulus dengan bertanya tentang hal-hal kecil tentang apa yang anak ketahui setelah menonton film Riko.

Tindakan dan kegiatan yang bervariasi yang belum dilakukan sebelumnya mampu meningkatkan rasa ingin tahu kepada anak. Selain itu, respons positif dan apresiasi harus dilakukan oleh orang tua saat anak bertanya tentang suatu hal. Bahkan, saat anak menceritakan pelajaran baru atau pengalaman baru yang ia dapat pada hari itu, orang tua harus memberikan respons positif.

Keberanian bertanya harus diapresiasi dan ditegaskan kalau anak boleh melakukan hal tersebut. Anak akan mengetahui bahwa bertanya bukanlah hal yang buruk dan boleh dilakukan dalam proses belajar dalam kehidupan sehari-hari.

Meskipun orang tua tidak bisa menjawab dengan detail, orang tua bisa memberitahu bahwa orang tua, dan anak bisa belajar bersama tentang suatu hal, orang tua perlu memberi statemen seperti, "Yuk, kita cari tahu, bagaimana ya proses ulat berubah menjadi kupu-kupu." Hal ini akan membuat anak merasa bahwa dia tidak belajar sendirian. Ke depan akan lebih banyak hal yang bisa ia tanyakan. Pendidikan karakter bisa efektif apabila orang tua menerapkan beberapa aspek antara lain: belajar, contoh, penegasan atau penguatan, dan pembiasaan secara bertahap (Sudrajat, 20II).

\section{Pendidikan Karakter Kerja Keras}

Pendidikan karakter yang paling utama adalah pendidikan karakter dalam keluarga. Orang tua berperan besar dalam proses pendidikan karakter ini. Hubungan orang tua, dan anak yang berlangsung selamanya menjadi faktor yang signifikan dalam perkembangan proses belajar (Hasibuan et al., 20I8). Dalam film Riko The Series season I diceritakan melalui dialog dan sikap tokoh Riko yang bekerja keras untuk mencapai sesuatu yang diinginkan, antara lain.

\begin{tabular}{cl}
\hline I & "Lihat nih QI IO. Mobil ini bisa kuperbaiki lagi," ujar Riko sembari menunjukkan mobil mainan yang \\
& telah berhasil ia perbaiki. (Riko: Eps. Mobilku Melaju Cepat). \\
\hline \multirow{2}{*}{2 "Kalau gitu Riko harus kuat, Riko mau kasih yang terbaik buat Allah,” tekad Riko. Dia berusaha } \\
menyelesaikan puasanya hingga adzan maghrib (Riko: Eps. Keutamaan Berpuasa). \\
\hline "Padahal, aku sudah hati-hati biar kelerengnya gak jatuh, tapi tetep aja." Riko menjelaskan kondisinya, \\
3 saat berusaha keras mempertahankan keseimbangan agar kelerengnya tidak terjatuh ke tanah. (Riko: \\
Eps. Peringatan Kemerdekaan Indonesia).
\end{tabular}

Dalam beberapa dialog dan sikap Riko di atas, dapat diketahui bahwa Riko merupakan tidak mudah menyerah dalam mencapai tujuannya. Karakter Riko ini menunjukkan bahwa Riko mempunyai karakter kerja keras dalam mencapai apa yang dia inginkan. Karakter bekerja keras ini menjadi penting untuk dikuatkan. Hal ini bertujuan untuk menguatkan kemauan anak dalam proses yang ia jalani untuk meraih keinginannya. Karakteristik bekerja keras meliputi perilaku individu yang mempunyai kecenderungan merasa gelisah saat pekerjaannya belum tuntas, sering mengecek atau memeriksa apa yang harus diselesaikan dalam tugas atau jabatannya, dan memiliki kemampuan dalam mengatur waktu dengan baik, serta memiliki kemampuan mengorganisasikan sumber daya yang tersedia untuk menuntaskan tugas dan tanggung jawab yang ada (Sulastri \& Alimin, 2017).

Dalam proses penguatan pendidikan karakter kerja keras, orang tua juga perlu memberikan penegasan kepada anak bahwa proses dalam meraih keinginan dengan usaha maksimal merupakan suatu hal yang baik. Karakter kerja keras sangat penting bagi anak. Berbagai dinamika yang akan terjadi diharapkan mampu dihadapi dengan karakter kerja keras yang sudah dikuatkan sejak anak usia dini (Sulastri et al., 2020). 


\section{Pendidikan Karakter Kreatif}

Karakter kreatif berkaitan dengan imajinasi. Imajinasi berkorelasi dengan pendidikan karakter, baik dalam proses pendidikan, penguatan, dan pembentukannya (Windiatmoko, 2016). Dalam proses pendidikan karakter ada proses pembentukan sistem secara sengaja yang diterapkan oleh orang dewasa dalam menanamkan nilai luhur, yakni pengetahuan, perasaan, dan perilaku atau tindakan (Muchtar \& Suryani, 2019). Dalam film Riko The Series season I diceritakan melalui dialog dan sikap tokoh Riko yang kreatif sebagai berikut.

\begin{tabular}{cl}
\hline I & $\begin{array}{l}\text { "QI IO, mobil ini sudah rusak. Sekarang aku akan coba memperbaikinya sendiri” (Riko: Eps. Mobilku } \\
\text { Melaju Cepat). }\end{array}$ \\
\hline 2 & $\begin{array}{l}\text { "QI IO, rudah bergerigi aku, rusak nih, patah, gak bisa lagi. Kita bikin yang baru yuk" (Riko: Eps. } \\
\text { Mobilku Melaju Cepat). }\end{array}$ \\
\hline & $\begin{array}{l}\text { Riko (memperbaiki pot dan tanaman Kak Wulan yang sudah dirusak). Adegan ini menunjukkan } \\
\text { bahwa Riko berpikir kreatif untuk memperbaiki pot dan tanaman yang rusak. (Riko: Eps. Tanaman } \\
\text { Bertasbih). }\end{array}$ \\
\hline
\end{tabular}

Dari beberapa dialog dan adegan dari sikap tokoh Riko saat menghadapi suatu permasalahan bisa diketahui bahwa Riko tanggap dalam berpikir. Dari adegan dan dialog di atas bisa kita ketahui bahwa Riko mempunyai karakter kreatif. Karakter ini cocok untuk dikuatkan pada anak sedini mungkin. Hal ini bertujuan untuk membuat anak menjadi berpikir kreatif di masa depannya.

Dalam penguatan karakter ini, orang tua bisa mengajak anak-anak untuk menyaksikan film animasi Riko The Series. Menonton film bersama-sama akan membangun kedekatan antara orang tua dan anak. Setelah menonton, orang tua bisa mengajak anak untuk berdiskusi. Apa pendapat mereka tentang film ini? Khususnya, membahas tindakan Riko yang kreatif dalam episode Mobilku Melaju Cepat atau Tanaman Bertasbih. Dalam dua episode ini terdapat karakter kreatif yang disajikan oleh tokoh Riko. Orang tua bisa mempertegas bahwa tindakan Riko baik untuk diterapkan dalam kehidupan sehari-hari. Penting bagi anak untuk mengetahui apa yang boleh dicontoh dan tidak boleh dari film yang sudah ditonton. Setelah anak mendapatkan pengetahuan ini, orang tua bisa mengajak anak untuk menyelesaikan suatu permasalahan. Misalnya, membetulkan mobil yang sudah rusak. Dalam proses ini, anak belajar menggunakan pikiran kreatifnya. Penerapan yang berulang-ulang akan menciptakan habbit atau kebiasaan di masa depan.

Apresiasi penting dilakukan oleh orang tua. Saat anak berhasil menyelesaikan permasalahan yang dihadapi, orang tua wajib memberikan apresiasi. Hal ini akan menimbulkan komunikasi yang baik antara orang tua dan anaknya.

\section{Pendidikan Karakter Mandiri}

Sikap dan perilaku tidak bergantung pada orang lain dan menggunakan seluruh tenaga, pemikiran, waktu untuk mewujudkan harapan, mimpi, dan cita-cita. Kemampuan seseorang menyelesaikan tanggung jawab yang dimiliki tanpa melibatkan orang lain dan memiliki keyakinan kuat terhadap kemampuan diri merupakan karakter mandiri (Napitupulu et al., 2019). Dalam film animasi Riko The Series season I diceritakan karakter tokoh Riko sebagai berikut. 


\begin{aligned} & \hline I $\begin{array}{l}\text { "Kok tidak ada yah?” ujar Riko sambil terus mencari barang ke dalam boks. Riko berusaha mencari } \\ \text { barangnya tanpa melibatkan orang lain. (Riko: Eps. Mobilku Melaju Cepat). }\end{array} \\ &$\hline $\begin{array}{l}\text { "Lagi cari body protector aku” kata Riko sambil terus mencari dalam boks penyimpanan. Dalam } \\ \text { adegan ini Riko tidak melibatkan orang lain dan berusaha sendiri terlebih dahulu (Riko: Eps. Lebih } \\ \text { Baik Memaafkan). }\end{array} \\ &$\hline "Sudah aku masukin ke dalam tas semua." Riko mengemas sendiri barang yang akan dibawa mudik. \\ & 3 $\begin{array}{l}\text { Riko tidak mengandalkan ibunya ataupun Kak Wulan, tapi mengemas barang bawaannya sendiri untuk } \\ \text { dibawa mudik Lebaran. (Riko: Eps. Ayahku Pahlawanku). }\end{array} \\ &$\hline $\begin{array}{l}\text { Riko merapikan kamar tidur. Dalam adegan ini terlihat Riko sedang membereskan tempat tidur dan } \\ \text { barang-barang di kamarnya tanpa melibatkan bunda atau Kak Wulan (Riko: Eps. Yuk Hemat Listrik). }\end{array} \\ &$\hline\end{aligned}

Beberapa dialog dan adegan di atas menunjukkan bahwa Riko tidak mengandalkan orang lain dalam mengurus kebutuhannya. Ia tidak mengandalkan bunda dan Kak Wulan untuk merapikan kamar tidur, dan tidak mengandalkan QIIO untuk mencarikan barangnya yang tidak ditemukan. Dalam dialog dan adegan tersebut bisa diketahui bahwa Riko mempunyai karakter mandiri dalam kehidupannya. Meskipun manusia adalah makhluk sosial, penguatan karakter mandiri juga sangat penting bagi anak. Hal ini bertujuan untuk menguatkan kemandirian anak agar tidak terlalu bergantung pada orang lain, dan bisa bertahan dalam segala situasi dan kondisi yang dihadapinya di masa depan.

Penguatan karakter ini bisa dimulai dengan menonton film animasi Riko bersama-sama. Pada episode Lebih Baik Memaafkan, ditunjukkan adegan Riko mencari sesuatu dalam boks penyimpanan. Orang tua bisa menegaskan bahwa perilaku ini boleh dilakukan dalam keseharian anak. Orang tua diharapkan memberikan apresiasi saat anak mampu menemukan barang yang dibutuhkan dengan usaha sendiri. Hal ini secara tidak langsung akan berpengaruh terhadap otak anak. Mereka akan melakukan hal yang sama karena merasa diapresiasi dan dihargai. Selain proses yang tersistematis, proses yang asyik perlu diterapkan dalam penguatan pendidikan karakter di masa pandemi Covid-I9.

Orang tua bisa memberikan pelatihan dengan meminta anak mencuci piring sendiri, melipat baju sendiri, dan mengerjakan pekerjaan sekolah secara mandiri. Apresiasi yang cukup akan membuat anak merasa lebih dihargai atas usahanya.

\section{Pendidikan Karakter Menghargai Prestasi}

Karakter menghargai prestasi juga disajikan dalam konten film animasi Riko The Series season I. Dialog dan sikap tokoh Riko yang menghargai prestasi orang lain dapat diuraikan sebagai berikut.

\begin{tabular}{|c|c|}
\hline $\mathrm{I}$ & $\begin{array}{l}\text { "Wah, aku juga haru bisa seperti dia." Riko bertekad bisa seperti Al Jazari (Riko: Eps. Mobilku Melaju } \\
\text { Cepat). }\end{array}$ \\
\hline 2 & $\begin{array}{l}\text { "Masyaa Allah, keren banget QI IO.” Riko melihat kemampuan QI IO dalam bermain acak kartu kata. } \\
\text { Adegan dan dialog ini menunjukkan bahwa Riko menghargai dan terkesan dengan kemampuan QI IO. } \\
\text { (Riko: Eps. Lawan Virus dengan Madu). }\end{array}$ \\
\hline 3 & $\begin{array}{l}\text { "Masyaa Allah, gitu," ucapnya kagum mendengar penjelasan tentang Albatani. Adegan ini juga } \\
\text { memperlihatkan sikap Riko yang menghargai prestasi ilmuan Albatani. (Riko: Eps. Jarak Matahari } \\
\text { dan Bumi). }\end{array}$ \\
\hline
\end{tabular}

Dari beberapa dialog dan adegan dalam film yang dipaparkan di atas, bisa disimpulkan bahwa Riko mempunyai menghargai suatu prestasi. Dia melakukan aktivitas secara mandiri dalam kehidupan sehari-hari. Karakter menghargai ini penting untuk dikuatkan. Hal ini bertujuan agar anak tidak memiliki sifat iri atau dengki kepada orang lain. Sebaliknya, dengan penguatan karakter menghargai prestasi diharapkan anak akan termotivasi dengan prestasi orang lain. Anak bisa terpacu dan termotivasi untuk berusaha meraih prestasi juga.

Tentu bukan hal mudah dalam menanamkan karakter ini. Sifat iri hati terhadap pencapaian orang lain tidak jarang terjadi. Ini menjadi momen yang tepat agar orang tua membangun komunikasi yang baik 
dengan anak. Di era wabah pandemi ini orang tua lebih banyak waktu di rumah. Kondisi tersebut dapat dijadikan sarana melakukan pendidikan nonformal di rumah. Pendidikan adalah sebuah proses panjang. Butuh waktu, kesabaran, dan ketekunan dalam mendapatkan tujuan yang ingin dicapai dengan pendidikan. Orang tua tidak perlu membandingkan anaknya dengan anak orang lain. Orang tua hanya perlu mengarahkan potensi sang anak. Sesudah mengetahui potensi ini, anak perlu dimotivasi agar bersemangat meraih tujuannya.

Film animasi Riko bisa ditonton bersama-sama. Selain menciptakan suasana yang menyenangkan, orang tua bisa mengedukasi anak melalui film ini. Episode Melaju Cepat menunjukkan bahwa tokoh Riko mengagumi keberhasilan seorang ilmuwan. Untuk itu, orang tua dapat menstimulus anak melalui kalimat persuasif. Misalnya, "Wah, hebat sekali yah ilmuwannya. Adek ingin jadi apa kalau besar nanti?" Lalu orang tua bisa mendengarkan keinginan anak dan memberikan dukungan lagi. "Wah, yuk berusaha. Dek. Berdoa juga yah, Adek pasti bisa. Mama sama Papa akan selalu mendoakan agar Adek bisa berhasil ya”. Kalimat persuasif dan penegasan bahwa keberhasilan orang lain adalah motivasi perlu diajarkan kepada anak. Setelah anak mengerti bahwa dia memiliki kesempatan untuk meraih kesuksesan, membantu anak dengan berlatih meraih apa yang dimaui. Apresiasi tetap diperlukan, bahkan saat anak gagal. Dukungan adalah segalanya untuk membangkitkan motivasi anak agar berusaha lagi di masa mendatang.

\section{Pendidikan Karakter Tanggung Jawab}

Dalam proses pendidikan karakter, anak akan tumbuh memahami emosinya. Tidak sekedar cerdas dalam pengetahuan, namun anak juga akan mengalami peningkatan kecerdasan emosi, sehingga anak mampu mengambil keputusan di masa depan dengan pertimbangan emosi yang matang (Yusuf, 20I5). Karakter bertanggung jawab juga terdapat dalam beberapa adegan film Riko The Series season I antara lain.

\begin{tabular}{|c|c|}
\hline I & $\begin{array}{l}\text { "Maafin Riko yah. Kemarin marah-marah sama Ayah." Riko meminta maaf kepada ayahnya atas } \\
\text { sikapnya yang tidak baik. (Riko: Eps. Ayahku Pahlawanku). }\end{array}$ \\
\hline 2 & $\begin{array}{l}\text { "Maafin Riko ya, Kak. Nanti tanamannya Riko ganti ya." Riko meminta maaf kepada Kak Wulan } \\
\text { dan ingin bertanggung jawab dengan mengganti tanaman yang tidak sengaja dia rusakkan. (Riko: Eps. } \\
\text { Tanaman Bettasbih). }\end{array}$ \\
\hline 3 & $\begin{array}{l}\text { "Tunggu ya, Kak Wulan. Alhamdulillah." Riko memperbaiki bunga yang tidak sengaja dia rusak. } \\
\text { Selain kreatif, tindakan Riko merupakan bentuk tanggung jawab dari perbuatan yang sudah dilakukan } \\
\text { (Riko: Eps. Tanaman Bertasbih). }\end{array}$ \\
\hline & $\begin{array}{l}\text { "Maaf Kak, Riko tadi dengernya kelinci." Riko meminta maaf atas kesalahannya dan mengakui bahwa } \\
\text { dia salah dengar apa yang dikatakan Kak Wulan kepadanya. (Riko: Eps. Yuk Hemat Listrik). }\end{array}$ \\
\hline
\end{tabular}

Dalam beberapa adegan dan dialog di atas, sikap Riko dalam mengakui kesalahannya dan bersedia meminta maaf merupakan salah satu bentuk dari tanggung jawab. Jadi, dapat disimpulkan bahwa Riko mempunyai karakter tanggung jawab dalam kehidupan sehari-hari. Karakter ini sangat penting untuk dikuatkan sejak dini. Tujuan penguatan karakter tanggung jawab yakni anak menjadi lebih berani dalam mengakui kesalahan, meminta maaf, dan bertanggung jawab atas segala keputusan yang diambilnya di masa depan.

Penguatan karakter tanggung jawab bisa dimulai melalui hal terkecil. Setelah menonton film animasi Riko The Series, orang tua dapat menegaskan bahwa bertanggung jawab itu sangat penting. Mengakui kesalahan dan meminta maaf bukanlah hal yang memalukan. Orang tua juga harus dapat memberi contoh. Saat tidak bisa memenuhi keinginan anak, misalnya, orang tua harus mampu meminta maaf. Begitu pula ketika melakukan kesalahan, baik yang disengaja maupun tidak disengaja.

Penting bagi anak untuk mengetahui bahwa bertanggung jawab itu penting. Berlatih dengan contoh setiap hari akan menjadikan kebiasaan. Ujaran "Maaf ya sayang. Sepertinya hari ini kita tidak bisa jalan-jalan karena hujan. Bagaimana kalau kita jalan-jalan di waktu yang lain? Sekarang kita main saja ya di rumah.” Dari contoh itu, tentu anak akan menyadari bahwa orang tua tidak ingkar janji. Anak dapat

Rizqy Dwi Rahmayanti, Yarno, \& R. Panji Hermoyo, Pendidikan karakter dalam film animasi Riko The Series produksi garis sepuluh 
melihat kondisi di sekitar yang tidak mendukung. Orang tua berani meminta maaf, sekaligus mendengarkan pendapat anak. "Meminta maaf bukan hal yang memalukan loh Nak. Kita harus berani mengakui kesalahan yang kita lakukan. Riko berani mengakui kesalahannya kepada Kak Wulan, dan dia tidak malu. Kak Wulan malah senang karena Riko meminta maaf dan memperbaiki kesalahannya, supaya tidak terulang lagi”.

Penelitian ini berfokus untuk menganalisis pendidikan karakter di dalam film animasi Riko The Series untuk dijadikan teladan bagi anak. Hasil dari analisis konten dalam film animasi ini sesuai dengan dugaan awal peneliti yang meyakini bahwa film animasi ini mampu dijadikan sebagai media penguatan pendidikan karakter positif bagi anak. Hasil analisis konten dalam penelitian ini menunjukkan bahwa karakter tokoh utama Riko mengandung enam karakter yang layak dijadikan teladan bagi anak sesuai dengan hasil analisis yang telah dijabarkan di atas.

\section{SIMPULAN}

Berdasarkan hasil analisis konten dalam film animasi Riko The Series terkandung karakterkarakter positif, yakni karakter religius, rasa ingin tahu, kerja keras, kreatif, mandiri, menghargai prestasi, dan tanggung jawab. Karakter ini mampu dijadikan teladan, sekaligus media penguatan pendidikan karakter melalui sastra yang layak bagi anak.

Film animasi ini mampu menjadi media pembelajaran yang layak dalam penguatan pendidikan karakter anak. Konsep edukasi dan entertainment yang diusung dalam film animasi ini bisa membuat proses pembelajaran lebih menarik dan tidak membosankan. Penggunaan bahasa dan visualisasi mudah dicerna dan ditiru oleh anak-anak. Anak sering meniru apa yang dilihatnya. Untuk itu, pendidik maupun orang tua bisa menggunakan film animasi ini sebagai media edukasi sekaligus hiburan bagi anak-anak dan peserta didik.

Penguatan pendidikan karakter merupakan sebuah proses yang bertujuan memperkuat karakter positif dalam diri anak, agar bisa menjadi kebiasaan dalam kehidupannya, dan terbawa hingga dewasa. Dibutuhkan waktu, kesabaran, dan konsistensi untuk mencapai tujuan tersebut.

\section{UCAPAN TERIMA KASIH}

Alhamdulillah, atas segala kemudahan yang diberikan oleh Allah SWT. Berkat doa kedua orang tua, serta dukungan bibi yang selalu memberikan motivasi dan doa terbaik. Terima kasih kepada kedua dosen pendamping yang senantiasa membimbing dan mendampingi dalam pembuatan artikel ini. Terima kasih untuk 'aku' yang sudah setia berjuang dalam awal proses pembuatan hingga penerbitan.

\section{DAFTAR PUSTAKA}

Ambarwati, A. (2017). Cerita bergambar untuk anak usia 0-3 tahun dalam tinjauan linguistik fungsional Halliday. KEMBARA: Jurnal Keilmuan Bahasa, Sastra, dan Pengajarannya (e-Journal), 2(2), I26135. https://doi.org/I0.22219/kembara.v2i2.3997

Anggraini, P. (2017). Citra tokoh perempuan dalam cerita anak Indonesia (sebuah pendekatan kritik feminisme). KEMBARA: Jurnal Keilmuan Bahasa, Sastra, dan Pengajarannya (e-Journal), 2(I), 67-76. https://doi.org/I0.22219/kembara.v2iI.4045

Arditiya, A. (2017). Internalisasi nilai ketuhanan pada novel Orang-orang Proyek karya Ahmad Tohari. KEMBARA: Jurnal Keilmuan Bahasa, Sastra, dan Pengajarannya (e-Journal), 2(2), I I4I25. https://doi.org/I0.22219/kembara.v2i2.3996

Azizah, A., \& Setiana, L. N. (2016). Karakter tokoh dalam novel Langit Mekah Berkabut Merah karya Geidurrahman Al-Mishry berbasis nilai-nilai karakter religius dan implikasinya dalam pembelajaran sastra di Madrasah Aliyah. Refleksi Edukatika: Jurnal Ilmiah Kependidikan, 7(I), 78-86. https://doi.org/I0.24I76/re.v7iI.I8I5 
Badruzaman, B., Hafidhuddin, D., \& Mujahidin, E. (2018). Pendidikan islami dalam pemikiran Hasan Langgulung. Ta'dibuna: Jumal Pendidikan Islam, $7(\mathrm{I}), \quad$ I-I9. http://dx.doi.org/I0.32832/tadibuna.v7iI.I34I

Cahyaningrum, E. S., Sudaryanti, S., \& Purwanto, N. A. (20I7). Pengembangan nilai-nilai karakter anak usia dini melalui pembiasaan dan keteladanan. Jurnal Pendidikan Anak, 6(2), 203-2I3. https://doi.org/I0.2I83I/jpa.v6i2.17707

Damayanti, E., \& Ikawati, A. (2018). Digital media dongeng berbasis animasi untuk pendidikan karakter anak usia dini. In Conference on Innovation and Application of Science and Technology (CIASTECH) (Vol. I, No. I, pp. 3I0-3I7). Retrived from http://publishingwidyagama.ac.id/ejournal-v2/index.php/ciastech/article/view/636

Demillah, A. (2019). Peran film animasi nussa dan rara dalam meningkatkan pemahaman tentang ajaran islam pada pelajar SD. Jurnal Interaksi: Jurnal Ilmu Komunikasi, 3(2), I06-II5. http:/ / dx.doi.org/I0.30596\%2Finteraksi.v3i2.3349

Fathurohman, I., Nurcahyo, A. D., \& Rondli, W. S. (20I4). Film Animasi sebagai media pembelajaran terpadu untuk memacu keaksaraan multibahasa pada siswa Sekolah Dasar. Refleksi Edukatika: Jurnal Ilmiah Kependidikan, 4(I), I-7. https:/ / doi.org/I0.24I76/re.v5iI.430

Hasibuan, A. A., Syah, D., \& Marzuki, M. (2018). Manajemen pendidikan karakter di SMA. Tarbawi: Jurnal Keilmuan Manajemen Pendidikan, 4(02), I9I-2I2. http://dx.doi.org/I0.32678/tarbawi.v4i02.I230

Ihsani, N., Kurniah, N., \& Suprapti, A. (2018). Hubungan metode pembiasaan dalam pembelajaran dengan disiplin anak usia dini. Jurnal Ilmiah Potensia, 3(2), I05-IIO. https://doi.org/I0.33369/jip.3.2.I05-IIO

Kurniati, E., Alfaeni, D. K. N., \& Andriani, F. (2020). Analisis peran orang tua dalam mendampingi anak di masa pandemi covid-19. Jurnal Obsesi: Jurnal Pendidikan Anak Usia Dini, 5(I), 24I-256. I0.3I004/obsesi.v5iI.54I

Kusmanto, H. (2020). Nilai-nilai pendidikan karakter pada wacana humor kiai. SALINGKA, Majalah Ilmiah Bahasa dan Sastra, I7(I), 29-4I.

Maunah, B. (2016). Implementasi pendidikan karakter dalam pembentukan kepribadian holistik siswa. Jurnal Pendidikan Karakter, I(I), 90-I0I. https://doi.org/I0.2I83I/jpk.v0iI.86I5

Melasarianti, L. (2016). Media film animasi bemuatan nilai nilai karakter sebagai uupaya meningkatkan keterambilan bercerita siswa Kelas VII A SMP Negeri Mandiraja Kabupaten Banjernegara tahun ajaran 29018/2019. Jumal Pendidikan Bahasa dan Sastra Indonesia, 3(2), 44-59. http://dx.doi.org/I0.23887/ivcej.v3i2.29707

Muchtar, D. (2019). Pendidikan karakter menurut Kemendikbud. Edumaspul: Jurnal Pendidikan, 3(2), 50-57. https://doi.org/I0.33487/edumaspul.v3i2.I42

Muhtar, T. (2020). Character education from the perspectives of elementary school physical education teachers. Cakrawala Pendidikan, 39(2), 395-408. https://doi.org/I0.21831/cp.v39i2.30647

Mustadi, A., Suhardi, S., Susilaningrum, E. S., Ummah, R., Wijayanti, P. E., \& Purwatiningtyas, M. (2018). Character-based reflective picture storybook: Improving students' social self-concept in elementary school (pp. I23-I30). Routledge.

Napitupulu, J. F. (2019). Nilai perilaku yang benar dalam buku teks bahasa Inggris kelas X SMA. KEMBARA: Jurnal Keilmuan Bahasa, Sastra, dan Pengajarannya, 5(I), 63-73. https://doi.org/I0.22219/kembara.v5iI.755I

Nugrahani, F. (2017). The development of film-based literary material which support character education. Junnal Cakrawala Pendidikan, 36(3), 472-486. https://doi.org/I0.2I83I/cp.v36i3.I42I9

Purbarani, Jatining Panglipur, E. L. (2010). Sastra anak sebagai sarana untuk menumbuhkan berbagai karakter di era global. PS PBSI FKIP Universitas Jember, 687-696. Retrived from http://jurnal.unej.ac.id/index.php/fkip-epro/article/view/4947 
Sakerebau, J. (20I8). Memahami peran psikologi pendidikan bagi pembelajaran. BIA': Jurnal Teologi dan Pendidikan Kristen Kontekstual, I(I), 96-III. https://doi.org/I0.34307/b.vIiI.22

Saraswati, E. (2017). Karakter kepemimpinan dalam Novel Silat Nagabumi karya Seno Gumira Ajidarma sebagai bahan ajar sastra di sekolah menengah. KEMBARA: Jurnal Keilmuan Bahasa, Sastra, dan Pengajarannya (e-Journal), 2(2), I57-I65. https://doi.org/I0.22219/kembara.v2i2.4000

Sayekti, O. M. (2019). Film animasi "Nussa dan Rara Episode Baik Itu Mudah" sebagai sarana penanaman karakter pada anak usia dini. Jurnal Pendidikan Anak, 8(2), I64-I7I. https://doi.org/I0.21831/jpa.v8i2.29093

Setiawan, A., \& Qur'ani, H. B. (2017). Nilai karakter cinta lingkungan melalui karakterisasi tokoh pada Novel Dari Rahim Ombak karya Tison Sahabuddin Bungin. KEMBARA: Jurnal Keilmuan Bahasa, Sastra, dan Pengajarannya, 3(2), I23-I34. https://doi.org/I0.22219/kembara.v3i2.5I6I

Shidiq, A. F., \& Raharjo, S. T. (2018). Peran pendidikan karakter di masa remaja sebagai pencegahan kenakalan remaja. Prosiding Penelitian dan Pengabdian kepada Masyarakat, 5(2), I76-I87. https://doi.org/I0.24198/jppm.v5i2.18369

Subadi, I. (2017). Pesan pendidikan karakter pada anak usia sekolah dalam serial film animasi Upin \& Ipin Episode "Iqra". eJournal Ilmu Komunikasi, 5(2), 8I-95. Retrived from https:/ / ejournal.ilkom.fisip-unmul.ac.id/site/wp-

content/uploads/20I7/05/Jurnal\%20imam\%20(\%20Cetak\%20)\%20(05-24-I7-I2-I54I).pdf

Sudrajat, A. (20II). Mengapa pendidikan karakter?. Jurnal Pendidikan Karakter, I(I), I-I2. https://doi.org/I0.2I83I/jpk.vIiI.I3I6

Sujinah, S. (2020). Tantangan dan solusi pembelajaran bahasa Indonesia di era covid-I9. Stilistika: Jurnal Pendidikan Bahasa dan Sastra, I3(2), 256-27I. http://dx.doi.org/I0.3065I/st.v13i2.5444

Sulastri, S. (2017). Nilai pendidikan karakter kerja keras dalam novel 2 karya Donny Dhirgantoro. Jurnal Pendidikan Bahasa, 6(2), I56-I68. http:/ /dx.doi.org/I0.3157I/bahasa.v6i2.6I9

Sulastri, S. (2020). Nilai pendidikan karakter kerja keras dalam novel Tentang Kamu Karya Tere Liye. Jurnal Penelitian dan Pengembangan Sains dan Humaniora, 4(I), 43-50. http://dx.doi.org/I0.23887/jppsh.v4iI.24336

Sulistiyo, U. (2020). Infusing moral content into primary school english textbooks: A critical discourse analysis. Indonesian Joumal of Applied Linguistics, IO(I), 25I-260. Retrived from https:// core.ac.uk/download/pdf/326768977.pdf

Supeni, S. (2015). Pengembangan model internalisasi pendidikan karakter pancasila pada guru pendidikan anak usia dini. Jurnal Cakrawala Pendidikan, 34(I), II8-I27. https://doi.org/I0.2I83I/cp.vIiI.4I82

Windiatmoko, D. U. (2017). Analisis wacana dalam gurindam XII dan nilai pendidikan karakter serta implikasinya sebagai materi ajar sastra. KEMBARA: Jurnal Keilmuan Bahasa, Sastra, dan Pengajarannya (e-Joumal), 2(I), I2-22. https://doi.org/I0.22219/kembara.v2iI.40I6

Yusuf, Y. (2015). Integrasi pendidikan karakter berbasis qurani dan kearifan lokal Bugis. Jumnal Studi Agama dan Masyarakat, II(2), 247-264. https://doi.org/I0.2397I/jsam.vIIi2.452

Zaeni, M. (2015). Sosok perempuan dalam naskah drama Arifin C. Noer. KEMBARA: Jurnal Keilmuan Bahasa, Sastra, dan Pengajarannya (e-Journal), I(2), 2I2-223. https://doi.org/I0.22219/kembara.vIi2.2617 